\title{
Quality Assessment methods for Ginger (Zingiber officinale): A review
}

\author{
Mai T. Abdo ${ }^{*}$, Haidy A. Gad, Sherweit H. El-Ahmady, Mohamed M. Al-Azizi \\ Department of Pharmacognosy, Faculty of Pharmacy, Ain Shams University, Abbassia, Cairo 11566, Egypt
}

\begin{abstract}
The rhizome of ginger (Zingiber officinale Roscoe) is a commonly used edible vegetable, condiment, and spice that are used worldwide for culinary, nutritional, medicinal and industrial purposes. Its great medicinal and economical value provide a great possibility for contamination and adulteration. Closely related species are usually used mistakenly as ginger and are hardly differentiated. A proper method of quality control is required for its authentication and analysis. This review discusses various techniques employed for the quality control of ginger including different chromatographic and spectroscopic methods, DNA profiling in addition to the application of multivariate analysis. The advantages and drawbacks of each method are presented as well as recommendations for improved quality assessment.
\end{abstract}

Keywords: Quality control; Ginger; Zingiber officinale.

*Correspondence | Mai T. Abdo; Department of Pharmacognosy, Faculty of Pharmacy, Ain Shams University, Abbassia, Cairo 11566, Egypt. Email: mai.tawfik@pharma.asu.edu.eg

Citation | Mai TA, Haidy AG, Sherweit HE, Mohamed MA. 2018. Quality Assessment methods for Ginger (Zingiber officinale): A review. Arch Pharm Sci ASU 2(2): 78-96

DOI: $10.21608 /$ aps.2018.18737

Online ISSN: 2356-8380. Print ISSN: 2356-8399.

Received 12 October 2018. Accepted 23 November 2018.

Copyright: ${ }^{{ }^{2}} 2018$ Abdo et al. This is an open-access article licensed under a Creative Commons Attribution 4.0 International License (CC BY 4.0), which permits unrestricted use, distribution, and reproduction in any medium, provided the original author(s) and source are credited

Published by: Ain Shams University, Faculty of Pharmacy

\section{INTRODUCTION}

Herbs and spices have been shown to alter our biological functioning, as methods of treatment for various ailments. Many medicinal plants have social and spiritual importance in different cultures and have played a role in ethnic beliefs throughout history. Plants have also shown pivotal significance in economic terms as important ingredients in foodstuff, medication, and cosmetics.

The rhizome of ginger (Zingiber officinale), a popular member of family Zingiberaceae has been widely used since ancient times. It is cultivated worldwide in many tropical and subtropical regions. Ginger has been extensively used as a spice in various cuisines like Chinese, Indian, Thai, and others, due to its aromatic and pungent characteristics. In addition, it is used as a flavor in different beverages and as a preservative in many marketed products. Furthermore, it has been regarded as an imperative medicinal plant in Ayurveda, Chinese, and Tibb-Unani traditional medication. Traditionally, ginger has been used to treat different ailments including nausea, sea or motion sickness, nausea correlated to pregnancy, 
vomiting, anorexia, gastrointestinal spasms, acidity, cramp, flatulence, diarrhea, dyspepsia, common cold, influenza, cough, osteoarthritis, inflammatory disorders, migraines, headaches, hypertension, cardiac palpitations and impotence [1]. Ginger (Zangabil in Arabic), has religious importance in the Middle East; mentioned in the holy Quran. Recent studies have renewed interest in ginger mainly due to its nonvolatile pungent constituents showing remarkable biological activities including anti-inflammatory, antiplatelet aggregation [2], antioxidant, immunomodulatory, anti-tumor, anti-apoptotic, hypoglycemic, hypolipidemic, anti-emetic actions [3], antihypertensive, antimicrobial and others [4].

Ginger is listed as "generally recognized as safe" (GRAS) by the Food and Drug Administration (FDA), USA [1]. The importance of ginger as a medicinal herb and a worldwide used spice makes it liable to adulteration as highquality ginger is mostly mixed with lower quality or exhausted samples to add volume or with lower price pungent materials, such as galangal, grains of paradise or capsicum to increase its pungency [5]. It is worth noting that in certain clinical trials investigating the activity of ginger as a crude extract or powder for the treatment of arthritis [6] or pregnancy-related nausea, $[7,8]$ have provided mixed and variable results and this may be attributed to the limited enforcement for standardization of ginger food supplements. Moreover, the quantity of ginger rhizome in each capsule (by weight) is only mentioned on the labels of these food supplements. Chemical standardization of these products to determine and label the precise active constituents is rarely achieved [9]. Thus, effective measures are required for the authentication and quality control of ginger to assure its safety and purity. The aim of this review is to present the reported methods for the quality control of ginger including different chromatographic and spectroscopic methods, DNA markers in addition to different hyphenated techniques in combination with chemometrics and provide insight on optimum methods of its quality control.

The data presented in this review were collected up to 2018 from various databases including SciFinder (https://scifinder.cas. org/SciFinder/login), Web of Knowledge (http://www.web ofknowledge.com) and PubMed (http://www.ncbi.nlm.nih. gov/PubMed).

\section{QUALITY CONTROL METHODS}

\subsection{Chromatographic techniques}

Chromatography is a common name for the techniques used for separation of molecules based on their structure and/or composition. Early chromatographic non-instrumental techniques as paper and column chromatography are still used till today for preliminary investigations and simple laboratory work. However, there is a great focus on the use of instrumental techniques as high-performance liquid chromatography (HPLC) and high-performance thin layer chromatography (HPTLC) for the reliable separation of different components of the analyzed mixtures. This is followed by structure elucidation of the separated components using different spectroscopic techniques, allowing for the qualitative and quantitative analysis of complex mixtures. Advantages of chromatography include operating at low temperature, the possibility of large scale or continuous operation, separation of molecules according to size and/or chemical characteristics, separation of sensitive and thermo-labile compounds and high purity of the separated compounds. Hence, chromatography is greatly exploited in food, nutrition and phytochemical studies [10]. Different chromatographic techniques have been utilized for the quality control of ginger such as thin layer chromatography (TLC), HPTLC, HPLC and gas 
chromatography (GC). Cited examples for the techniques for the quality control of ginger are application of different chromatographic summarized in Table 1.

Table 1. Application of different chromatographic techniques for the quality control of ginger

\begin{tabular}{|c|c|c|c|}
\hline Extraction & $\begin{array}{l}\text { Method of } \\
\text { analysis }\end{array}$ & Purpose of the study & Reference \\
\hline $\begin{array}{l}\text { Samples }(20-50 \mu \mathrm{g}) \text { in } 4 \% \text { ether } \\
\text { solution were used for spotting } \\
\text { Mobile phase: } \\
\text { Anhydrous diethyl ether: n- } \\
\text { hexane }(4: 1, \mathrm{v} / \mathrm{v})\end{array}$ & TLC & Quality control of ginger & [11] \\
\hline $\begin{array}{l}\text { Methanol extract } \\
\text { Mobile phase: } \\
\text { n-hexane : ethyl ether }(4: 6, \mathrm{v} / \mathrm{v})\end{array}$ & $\begin{array}{c}\text { TLC } \\
\text { densitometric } \\
\text { method }\end{array}$ & $\begin{array}{l}\text { Detection of 6-gingerol and 6-school in } \\
\text { some marketed gingers }\end{array}$ & [12] \\
\hline $\begin{array}{l}\text { Methanol extract } \\
\text { Mobile phase: } \\
\text { Toluene : ethyl acetate }(3: 1, \mathrm{v} / \mathrm{v})\end{array}$ & HPTLC & $\begin{array}{l}\text { Determination of 6-gingerol, 8-gingerol, } \\
\text { 10-gingerol, and 6-shogaol in some } \\
\text { commercial gingers }\end{array}$ & {$[14]$} \\
\hline $\begin{array}{l}\text { Methanol extract } \\
\text { Mobile phase: } \\
\text { n-hexane : ethyl acetate(5:5, } \\
\text { v/v) }\end{array}$ & HPTLC & $\begin{array}{l}\text { Determination of the quantity of } 10- \\
\text { gingerol in ginger extract and ginger- } \\
\text { containing dietary supplements, teas and } \\
\text { commercial creams }\end{array}$ & [15] \\
\hline $\begin{array}{l}\text { Methanol extract } \\
\text { Mobile phase: }\end{array}$ & HPTLC & $\begin{array}{l}\text { Determination of the quantity of 6- } \\
\text { gingerol in ginger extract and ginger- } \\
\text { containing dietary supplements, teas and }\end{array}$ & {$[16]$} \\
\hline
\end{tabular}




\begin{tabular}{|c|c|c|c|}
\hline $\begin{array}{l}\text { n-hexane: ethyl acetate } \\
(4: 6, v / v)\end{array}$ & & commercial creams & \\
\hline $\begin{array}{l}\text { Methanol extract } \\
\text { Mobile phase: } \\
\text { Acetonitrile : water : formic acid } \\
(7: 2: 1, \mathrm{v} / \mathrm{v} / \mathrm{v})\end{array}$ & RP_HPTLC & $\begin{array}{l}\text { Quantitative analysis of } 6,8 \text { and } 10- \\
\text { gingerols from the methanol extract of } \\
\text { fresh ginger rhizomes collected from the } \\
\text { northwestern Himalayas }\end{array}$ & [17] \\
\hline $\begin{array}{l}\text { Methanol extract } \\
\text { Mobile phase: } \\
\text { Hexane: ethyl acetate: formic } \\
\text { acid }(5.5: 4: 0.5, \mathrm{v} / \mathrm{v} / \mathrm{v})\end{array}$ & $\begin{array}{l}\text { HPTLC } \\
\text { HPLC }\end{array}$ & $\begin{array}{l}\text { Chemical profiling of four Jamaican } \\
\text { ginger cultivars, comparison of the } \\
\text { composition of oleoresin of ginger } \\
\text { collected at different aging stages }\end{array}$ & [18] \\
\hline $\begin{array}{l}\text { Ethanol extract } \\
\text { Isocratic elution } \\
\text { Mobile phase: } \\
\text { Acetonitrile : } 2 \% \text { aq. acetic acid } \\
(2: 3, v / v)\end{array}$ & HPLC-UV & $\begin{array}{l}\text { Direct detection of the major ginger } \\
\text { pungency compounds }\end{array}$ & [19] \\
\hline $\begin{array}{l}\text { Acetone extract } \\
\text { Linear gradient elution } \\
\text { Mobile phase: } \\
\text { Methanol: water }(6.5: 3.5, \mathrm{v} / \mathrm{v})\end{array}$ & HPLC-UV & $\begin{array}{l}\text { Determination of pungent gingerol } \\
\text { compounds in green and dry ginger }\end{array}$ & [20] \\
\hline $\begin{array}{l}\text { Methanol extract } \\
\text { Gradient elution } \\
\text { Mobile phase: }\end{array}$ & $\begin{array}{l}\text { HPLC-UV- } \\
\text { ES/MS }\end{array}$ & $\begin{array}{l}\text { Identify the individual constituents } \\
\text { responsible for the pungency of fresh } \\
\text { ginger }\end{array}$ & [21] \\
\hline
\end{tabular}




\begin{tabular}{|c|c|c|c|}
\hline Water: Acetonitrile & & & \\
\hline $\begin{array}{l}\text { Ethanol extract } \\
\text { Isocratic elution } \\
\text { Mobile phase: } \\
\text { Methanol: Water }(7: 3, \mathrm{v} / \mathrm{v})\end{array}$ & HPLC-UV & $\begin{array}{l}\text { Detection of the pungency of fresh, sun- } \\
\text { dried and sun-dried/steam distilled } \\
\text { ginger rhizomes in a relation to the } \\
\text { content of 6-gingerol }\end{array}$ & [22] \\
\hline $\begin{array}{l}\text { Methanol extract } \\
\text { Mobile phase: } \\
\text { Superheated deuterium oxide }\end{array}$ & HPLC-NMR & $\begin{array}{l}\text { Separation and analysis of the } \\
\text { constituents of ginger extract. }\end{array}$ & [23] \\
\hline $\begin{array}{l}\text { Ethyl acetate and ethanolic } \\
\text { extracts } \\
\text { Mobile phase: } \\
\text { Methanol: Water }(6.5: 3.5, \mathrm{v} / \mathrm{v})\end{array}$ & HPLC-UV & $\begin{array}{l}\text { Analysis of 6-, 8-, 10-gingerols and 6- } \\
\text { shagoal in ethyl acetate and ethanolic } \\
\text { extracts of ginger-containing dietary } \\
\text { supplement, teas, spices, and drinks. }\end{array}$ & (24) \\
\hline $\begin{array}{l}\text { Methanol extract } \\
\text { Linear gradient elution } \\
\text { Mobile phase: } \\
\text { Acetonitrile: Water }\end{array}$ & HPLC-UV & $\begin{array}{l}\text { Simultaneous determination of 6-, 8- } \\
\text { and } 10 \text {-gingerols in three medicinal } \\
\text { gingers }\end{array}$ & [25] \\
\hline $\begin{array}{l}\text { Methanol extract } \\
\text { Chloroform extract } \\
\text { Linear Gradient elution } \\
\text { Mobile phase: } \\
\text { Acetonitrile: Water with } 1 \% \\
\text { formic acid }\end{array}$ & $\begin{array}{l}\text { HPLC- } \\
\text { MS/MS }\end{array}$ & $\begin{array}{l}\text { Identification and quantification of } \\
\text { gingerols and other compounds in } \\
\text { ginger-containing dietary supplements }\end{array}$ & [9] \\
\hline
\end{tabular}




\begin{tabular}{|c|c|c|c|}
\hline $\begin{array}{l}\text { Methanol extract } \\
\text { Gradient elution } \\
\text { Mobile phase: } \\
\text { Solvent A: sodium phosphate } \\
\text { buffer } \\
\text { Solvent B: sodium phosphate } \\
\text { buffer containing } 58.5 \% \\
\text { acetonitrile and } 12.5 \% \\
\text { tetrahydrofuran }\end{array}$ & HPLC-ECD & $\begin{array}{l}\text { Quantification of } 8 \text { known ginger } \\
\text { components (6-, 8-, and 10-gingerol, 6-, } \\
8 \text {-and 10-shogaol, 6-paradol, and 1- } \\
\text { dehydrogingerdione) in } 11 \text { ginger- } \\
\text { containing marketable products }\end{array}$ & [26] \\
\hline $\begin{array}{l}\text { Ethyl acetate extract } \\
\text { Hot water extract } \\
\text { Gradient elution } \\
\text { Mobile phase: } \\
\text { Acetonitrile: Water with } 0.5 \mathrm{mM} \\
\text { ammonium formate and } 0.1 \% \\
\text { formic acid }\end{array}$ & $\begin{array}{l}\text { HPLC- } \\
\text { TOF/MS }\end{array}$ & $\begin{array}{l}\text { Instantaneous isolation, detection, and } \\
\text { quantitative analysis of gingerol-related } \\
\text { compounds in ginger products }\end{array}$ & [27] \\
\hline $\begin{array}{l}\text { Liquid carbon dioxide } \\
\text { ginger oil }\end{array}$ & "GC-MS & $\begin{array}{l}\text { Analysis of volatile constituents of } \\
\text { ginger oil }\end{array}$ & [28] \\
\hline n-hexane & GC-MS & $\begin{array}{l}\text { Determining the compounds responsible } \\
\text { for the characteristic odor of Japanese } \\
\text { ginger }\end{array}$ & [29] \\
\hline SPME & 2D GC-MS & $\begin{array}{l}\text { Identification and qualitative } \\
\text { comparison of the volatile constituents } \\
\text { of fresh and crystallized sweet ginger }\end{array}$ & [30] \\
\hline
\end{tabular}




\begin{tabular}{|l|l|l|c|}
\hline MD-SPME & GC-MS & $\begin{array}{l}\text { Analysis of volatile oil compounds in } \\
\text { fresh ginger and its comparison with } \\
\text { conventional SPME }\end{array}$ & [31] \\
\hline SDE, PEE and HS-SPME & GC-MS & $\begin{array}{l}\text { Identification of volatile components } \\
\text { extracted by three extraction methods }\end{array}$ & [32] \\
\hline Hydrodistillation & GC-FID & $\begin{array}{l}\text { Comparing the chemical composition of } \\
\text { fresh and dried ginger }\end{array}$ & [33] \\
\hline
\end{tabular}

\subsubsection{Thin layer chromatography}

TLC is considered the earliest utilized method for the quality control of most herbal extracts for its ease of use, simple and low cost. In 1972, Connell assigned a TLC method for the quality control of ginger. The results showed limited use of this method in the qualitative analysis due to the variability of results and lack reproducibility [11].

In 2007, Melianita et al. settled a TLC densitometric method for the detection of 6gingerol and 6-shogaol in some marketed gingers. Quantitative analysis of the methanolic extract of ginger was carried out by measuring the UV absorbance of the analytic spots at wavelength $\lambda=$ $577 \mathrm{~nm}$. However, this method detected only 6shogaol and 6-gingerol neglecting the rest of the significant constituents in ginger [12].

\subsubsection{High-performance thin layer chromatography}

Recently, increased level of sophistication and modifications have been implemented to TLC including higher quality silica plates with much smaller particle and pore size, higher packing density and smoother surface providing superior separation power, better sample diffusion, increased analysis speed and enhanced sensitivity of detection known as HPTLC(high performance liquid chromatography) [13]. Thus, it became a common method of analysis with the advantages of being reliable, sensitive, relatively low price and could be used for quantitative analysis using small amounts of sample and mobile phase thus being eco-friendly. In addition, it allowed for simultaneous assay of several components in multicomponent formulations and utilizing diverse methods of detection, which provided a multidimensional plant profiling, in comparison to the usual single-dimensional chromatogram of HPLC. However, the disadvantages included its inability to identify foreign organic or inorganic matter and afford a non-chemical assessment of quality [13].

In 2009, Melianita et al. modified the method performed in 2007 to apply HPTLC. This method was reported to be less expensive when compared to gas chromatography-mass spectrometry, liquid chromatography-mass spectrometry and even with high-performance liquid chromatography equipped with UV diode array detector [14]. A similar method was utilized for the quantitative detection of 6-gingerol and 10-gingerol in ginger extract and ginger-containing commercial products and dietary supplements from local markets of Riyadh, Saudi Arabia [15, 16]. 
In 2010, Khan et al. adopted an RP-HPTLC method for quantitative analysis of 6,8 and 10gingerols from the methanol extract of fresh ginger rhizomes collected from northwestern Himalayas [17].

In 2011, Salmon et al. used HPTLC for fingerprinting analysis of Jamaican ginger and to chemically profile four Jamaican ginger cultivars. In addition, this developed method was applied for comparing the composition of oleoresins of ginger collected at different aging stages $(7,8$ and 9 months) from eight geographical regions of Jamaica. Furthermore, stability investigation showed a noticeable change of the chemical constituents of ginger samples stored at $70^{\circ} \mathrm{C}$, which was observed by apparent differences in the HPTLC profile. This analysis revealed that the oleoresins stored at $4{ }^{\circ} \mathrm{C}$ and $25{ }^{\circ} \mathrm{C}$ were stable for a minimum of 6 months. In addition, the study identified 6, 8, 10-gingerols and 6shagoal as reference markers that could be used for the standardization of ginger products. The results indicated chemical homogeneity of the four cultivars together with aging samples collected from different parts of Jamaica. As a conclusion, the study presented this method is suitable for rapidly detecting the authenticity and quality of the ginger products. However, HPTLC showed a major disadvantage of low reproducibility as well as the chemical resemblance among the four cultivars. On the other hand, the HPLC investigation (discussed later) showed significant variance in total pungency levels and content of the essential oil [18].

\subsubsection{High-performance chromatography}

liquid

HPLC is considered one of the primary tools of quantitative analysis. It has been applied either for obtaining characteristic chemical fingerprints and chemical profiling for quantitative purposes.
Regarding its use in the quality control of ginger, HPLC was shown to be the most commonly used technique, however; quantification requires authentic reference markers including gingerols and shogaols.

In 1985, Baranowski developed the first HPLC method for the quantitative analysis of ginger using the spectra of authentic 6-gingerol for identification. The results showed that this method could be used for rapid analysis of ginger pungency, detecting changes during drying, processing and possible detection of adulteration [19].

Chen et al. (1986) designed an HPLC method for the analysis of acetone extracts of both green (4-5 months after planting) and dry ginger (8-9 months after planting). The gradient elution programming used in this study showed a better separation than the isocratic elution suggested by Baranowski. The results showed that different concentration ranges of pungent gingerol compounds offered a possible reference to differentiate or evaluate the maturity of raw materials [20].

In 1998, He et al. utilized electrospray mass spectrometry for the first time with HPLC-UV to identify the individual constituents responsible for the pungency of fresh ginger methanolic extract. Electrospray mass spectrometry provides an advantage of analysis of thermo-labile compounds including gingerols. The results showed that UV at $280 \mathrm{~nm}$ was more selective for the detection of gingerols and shogaols rather than $230 \mathrm{~nm}$ as previously reported [21].

Later on, Balladin et al. (1998) adopted an HPLC method for the detection of the pungency of fresh, sun-dried and sun-dried/steam distilled ginger rhizomes in a relation to the content of 6gingerol. Reference standards of synthetic [n]gingerols, [n]-shogaols synthesized using regioselective aldol condensation of zingerone and 
corresponding aldehyde (verified by NMR spectroscopy) were used. The method was established to detect the level of the pungency of extracted ginger oleoresin, detection of any contaminants and stability studies of marketed ginger oleoresins [22].

The first report of utilizing nuclear magnetic resonance spectroscopy coupled with highperformance liquid chromatography (HPLCNMR) was by Saha et al. (2003). Through NMR, unidentified peaks were detected without the need for referenced standards as necessitated by previous methods. Moreover, this study involved the use of superheated water chromatography with deuterium dioxide $\left(\mathrm{D}_{2} \mathrm{O}\right)$ as an eluent for the separation of ginger extract, avoiding interfering signals with the spectra of the analytes. The analysis showed spectra for vanillin, dihydroferulic acid, zingerone and ferulic acid [23].

Later, in 2007, Schwertner et al. adopted HPLC for the analysis of 6-,8-,10-gingerols and 6-shagoal in ethyl acetate and ethanolic extracts of ginger-containing dietary supplement, teas, spices, and drinks. It was found the amounts of 6gingerol and 6-shagoal obtained from both extracts were similar. However, ethyl acetate was selected as the extraction solvent due to its immiscibility with water and thus could be used to extract ginger-containing drinks. Furthermore, ethyl acetate having lower polarity than ethanol would likely cause minor co-extraction interference. The study also compared the use of C-8 against C-18 reverse phase columns and concluded $\mathrm{C}-8$ to give better resolution for quantification of 6-, 8-, 10-gingerols and 6shagoal using external standards rather than the C-18 column [24].

In 2008, Li et al. used an HPLC-DAD method for simultaneous determination of 6-, 8- and 10gingerols in three gingers samples. The developed method involved using C-18 column and 6-, 8- and 10-gingerols as reference standards for their detection in dried, baked and fresh ginger [25].

Tandem mass spectrometry along with HPLC (LC-MS/MS) was adopted by Tao et al. (2009) for the identification and quantitative analysis of gingerols, shogaols, parasols, and gingerdiones in the chloroform extract of ginger-containing dietary supplements. This method was also used for the quantification of 6-gingerol, 8-gingerol, 10-gingerol, 6-shogaol, 8-shogaol, and 10shogaol with selected reaction monitoring in ginger dietary supplements. In this study, constant neutral loss scanning in the range $\mathrm{m} / \mathrm{z}$ 80-500 was investigated for the detection of selective neutral loss for gingerols. Results showed that neutral loss scanning of 194 or $136 \mathrm{u}$ can be used to detect specifically most gingerolrelated compounds (except for gingerols), that was in spite of the complex nature of ginger extracts [9].

In 2010, another electrochemical array detector (ECD) coupled with HPLC method was reported by Shao et al. for quantification of 8 known ginger components (6-, 8-, and 10gingerol, 6-, 8-, and 10-shogaol, 6-paradol, and 1dehydrogingerdione) in 11 ginger-containing marketed products. This study showed that the use of ECD was advantageous over the use of electrospray or UV detectors due to its high sensitivity for redox-sensitive components as found in ginger. However, there was one disadvantage of requiring a constant level of electrolyte within a suitable range in the mobile phases [26].

In 2012, Time-of-flight mass spectrometry (TOF) coupled with HPLC was first used and reported by Park et al. for instantaneous isolation, detection, and quantitative analysis of gingerolrelated compounds in ginger products. Ethyl acetate extracts of fresh and powdered dry gingers, hot water ginger extracts, and ginger teas 
were the topic of investigation. This method showed 70-100 times higher sensitivity when compared to the ordinary HPLC-UV detection method. However, this study could not compare the sensitivity of the LC-TOF/MS method directly with that of LC-MS/MS. Furthermore, this method identified 19-gingerol-related compounds (4-, 6-, 8-, 10-, and 12-gingerols, methyl-6-, methyl-8-, and dehydro-6-, dehydro-8, dehydro-10-, and dehydro-12-gingerols, dehydro6-, dehydro-8-, dehydro-10-, dehydro-12-, dehydro-14-gingerdione, and 6-, 8-, and 10shogaols), which is much more than any other previously reported method. This study also supported the previous hypothesis suggesting that shogaols are not intrinsic components of fresh authentic ginger but are considered chemical degradation products of gingerols during ginger processing and exposure to heat [27]. The use of LC-TOF/MS allowed for the ability of untargeted detection with the all-time recorded full spectrum, which was not possible with LCtandem MS. Thus, this method could be used for the detection of low levels of gingerols and shogaols in ginger-containing commercial products [27].

\subsubsection{Gas chromatography (GC)}

Gas chromatography has been widely used for the detection of volatile constituents and is considered the first choice in the quantitative analysis of essential oils and volatile substances. Regarding ginger, GC has been used mainly for the analysis and identification of its volatile components rather than its quality control. This is mainly due to the inability to detect pungent components of ginger due to their thermal instability [26]. Studies using gas chromatography were performed for either overcoming this problem or investigating a better extraction method for the volatile constituents of ginger.
In 1988, Chen et al. used GC-MS for the analysis of volatile constituents of ginger oil extracted with liquid carbon dioxide used to overcome the thermal instability that might occur due to steam distillation [28].

In 1995, Nishimura utilized a modified multidimensional GC-MS for determining the compounds responsible for the characteristic odor of Japanese ginger. Aroma extraction dilution analysis was used for the detection of the flavor dilution factor (FD). Compounds with high FD appeared to have the most noticeable flavor in the fresh rhizomes of ginger. These compounds included geranial, geraniol, linalool, neral, borneol, and isoborneol. In addition new compounds including (E)-2-alkenals, 2-octyl acetate, 2-pinen-5-o1,2-(2',3'-epoxy-3'-methyl butyl)-3-methylfuran, and (E)- and (Z)-3,7dimethy1-3,6-octadienal were also identified. This study showed that the characteristic flavor of ginger was not related particularly to one compound but a mixture of highly flavored oxygenated compounds (monoterpenoids and (E)-2-alkenals) [29].

Solid phase micro-extraction (SPME) was used by Shao et al. in 2003 for the extraction of the volatile oil from both fresh ginger and crystallized ginger sweets. Two-dimensional gas chromatography was used for the identification and qualitative comparison of their volatile constituents. Both fresh and sugar crystallized ginger, showed the same heavy compounds, however, sugar crystallized ginger sweet showed lower content of components of higher volatility. Concerning pungent principles, this method could detect neither gingerols nor shogaols, as gingerols are thermally unstable and shogaols are rarely found in fresh ginger [30].

In 2007, Yu et al. used GC-MS following microwave distillation and solid-phase microextraction (MD-SPME) for the analysis of volatile oil compounds in fresh ginger. MD- 
SPME allowed for instantaneous isolation, concentration, and extraction of volatile constituents, where, 54 components were identified including geranial, zingiberene, $\beta$ sesquiphellandrene, and $\beta$-phellandrene. However, conventional SPME resulted in the identification of only 34 components. In addition, MD-SPME provided additive advantages of requiring less amount of sample, without the need for organic solvent nor water for the analysis [31].

In 2009, Yang et al. compared between three different extraction methods for extracting the volatile components of ginger: steam distillation extraction (SDE), petrol ether extraction (PEE) and headspace solid-phase microextraction (HS-SPME). GS-MS was used for the identification of volatile components extracted by these methods. HS-SPME method was concluded as simple, fast and efficient for extraction and semi-quantitation of volatile constituents of ginger rhizome [32].

For comparing the chemical composition of fresh and dried ginger in 2010, Sasidharan et al. used GC-FID and GC-MS. Zingiberene appears to be the major compound in both oils but with different ratios. Dried ginger oil showed lower content of sesquiterpene alcohols, oxygenated compounds, and monoterpene content except for myrcene [33].

\subsection{Spectroscopic techniques}

\subsubsection{Ultraviolet spectroscopy}

In 2012, Shinde et al. developed a UV spectroscopic method for quick detection of gingerol in the ginger extract. The method showed the $\lambda$ max of ginger as $281.40 \mathrm{~nm}$. The developed method was capable to quickly quantify ginger extract in a variety of products. However, this method lacked sensitivity and could not be used for the definitive detection of individual components of ginger [34].

\subsection{DNA-based markers}

Despite the various methods previously described for the quality control of ginger, limitation in the differentiation of ginger (Zingiber officinale) from closely related species as bitter or pinecone ginger (Zingiber zerumbet) and Thai or Cassumunar ginger (Zingiber cassumunar) remains a problem. The similarity of the rhizome morphology of these two species to that of Zingiber officinale allows for their use as adulterants. Recent genetic tools that applied polymerase chain reaction (PCR), cloning, sequencing and hybridization procedures provided more accurate and satisfying methods for authenticating medicinal herbs [35]. Supplementary methods for definitive detection and authentication of ginger are useful including DNA-based molecular markers methods [36].

In 2006, Jiang et al. used phylogenetic analysis based on molecular data to study the genetic variability of ginger obtained from different geographical sources. In addition, differences between ginger (Zingiber officinale) and other medicinally used Zingiber species were investigated. Z. zerumbet, Z.montanum, Z. mioga, $Z$. spectabile, and Alpinia galangal were selected due to their common use as adulterants of ginger and/or their use as medicinal plants. In addition, galangal was used as the outgroup (non-ginger) for the phylogenetic analysis. Even though ginger obtained from different geographical sources showed similar phylogenetic analysis, however, differentiation between ginger and other Zingiber species based on the sequence data was achieved. The drawback for this method was the difficulty to obtain DNA from commercial gingercontaining products as it is often sold as a ground powder or as non-polar solvent extract [37].

Later on, the authentication of ginger in ginger-containing marketed products was accomplished by Chavan et al. (2008) where a DNA-based molecular markers method was developed using SCAR (sequence-characterized amplified region). Screening of DNA from several parts of $Z$. officinale, $Z$. zerumbet and $Z$. cassumunar were performed using RAPD (random amplification of polymorphic DNA) primers followed by cloning and sequencing of 
the RAPD bands unique to $Z$. officinale. Longer species-specific PCR primers were developed using this sequence information to amplify specific SCAR markers for distinguishing $Z$. officinale from the other selected Zingiber species, as well as commonly used medicinal plants in ginger-containing commercial products. Furthermore, these SCAR markers were tested in Trikatu [a mixture of dried, semi-processed powders of $Z$. officinale, Pi. nigrum (Black pepper) and Pi. longum (Long pepper)] as well as individual powders of each of the three medicinal plants to ensure that it specifically amplifies the desired marker in $Z$. officinale. In addition, SCAR primers were run on DNA samples of some other commonly used Ayurvedic medicinal plant species that are likely to be found with ginger in multicomponent formulations. The developed method was proposed as a complementary tool for differentiating $Z$. officinale from other Zingiber species [36]. The disadvantages of this method included the use of sophisticated instrumentation as PCR, gel analysis and long analysis time.
Recently, Chaudhary et al. (2014) tried to overcome the disadvantages of the previous method by developing a loop-mediated isothermal amplification (LAMP)-based marker method for DNA authentication of Zingiber officinale and studied their suitability for the analysis of fresh, dried powder and multicomponent ginger-containing formulations. The method involved twelve rhizome samples of ginger and closely related species screened with randomly amplified polymorphic DNA (RAPD). The procedure involved eluting, cloning and sequencing of the common noticeable DNA fragment in all samples. This developed method was recommended for use when botanical authentication of ginger from closely morphologically related species was difficult, such as in the case of incomplete or damaged samples and in dried herbal products [38]. Cited examples for the application of different DNAbased markers for the quality control of ginger are summarized in Table 2.

Table 2. Application of DNA-based marker for the quality control of ginger

\begin{tabular}{|l|l|c|}
\hline Method of analysis & \multicolumn{1}{|c|}{ Purpose of the study } & Reference \\
\hline $\begin{array}{l}\text { Phylogenetic analysis } \\
\text { based on molecular data }\end{array}$ & $\begin{array}{l}\text { Study the genetic variability of ginger obtained from } \\
\text { different geographical sources and differentiation between } \\
\text { ginger (Zingiber officinale) and other medicinally used } \\
\text { Zingiber species }\end{array}$ & [37] \\
$\begin{array}{l}\text { markers method using } \\
\text { SCAR }\end{array}$ & $\begin{array}{l}\text { Authentication of ginger in ginger-containing market } \\
\text { products and identification of Zingiber officinale from } \\
\text { multicomponent formulations. }\end{array}$ & [36] \\
\hline $\begin{array}{l}\text { DNA-based molecular } \\
\text { markers method using } \\
\text { (LAMP) }\end{array}$ & $\begin{array}{l}\text { Rapid and easy molecular authentication of the medicinal } \\
\text { plant Zingiber officinale Roscoe }\end{array}$ & [38] \\
\hline
\end{tabular}




\subsection{Different chromatographic techniques coupled to Chemometrics (Multivariate analysis)}

As previously discussed, most analytical methods used till now for the quality control of ginger and even other herbal extracts depended on the use of one or few markers present in the sample of pharmacologically activity and/or significant concentration. This is acceptable and successful if the target was the assessment of certain components. However, this strategy neglects other components present in the extract, which might add to the therapeutic activity of the herb. In addition, these other components may vary considerably depending on collection season, drying process, geographical origin, storage and other factors, which may affect the activity and stability of the plant extract. Hence, these methods do not provide a complete picture of the sample in question and are probably one of the reasons for the variability of results of clinical trials and investigations involving the use of herbal extracts. To overcome this problem, the necessity to develop a complete profile of the phytochemical constituents of the plant sample in question (fingerprint) arises in order to guarantee the consistency and reproducibility of pharmacological and clinical studies. This will also allow for the understanding of their biological activity, pharmacokinetics and possible side effects and to assure authenticity and quality of the product. This is the so-called fingerprint analysis. Chromatographic fingerprint techniques can be used to analyze both the marker compounds and the unknown constituents in multicomponent herbal formulations, which is recommended by the US Food and Drug Administration, the European Medicines Evaluation Agency, and State Food and Drug Administration of China (SFDA) to judge the quality, authenticity, and stability of botanical products (39). Fingerprinting analysis using the commonly used analytical tools as (HPLC, GC, and HPTLC) together with different spectroscopic methods as (UV, IR and mass spectroscopy) reflects the complex chemical composition of herbal extracts. Despite the possibility of differentiating the different extract chromatograms visually, to rely on this process is usually inaccurate, biased and non-quantitative. In addition, missing minor differences between very closely related species might occur. These disadvantages are tackled by combining fingerprinting analysis together with chemometric methods (multivariate analysis). Recent coupling of chromatographic techniques and fast-developing chemometrics analysis methods offers dominant tools to analyze the overlapping peaks of complex multicomponent herbal formulations [40].

As an application of chemometrics for fingerprinting analysis of Chinese herbs in 2001, Chau et al. used 2D GC-MS coupled with chemometrics for producing a chemical fingerprint for fresh and dried ginger samples. This study showed that steam distillation showed more extraction efficiency of volatile components from both fresh and dried ginger than Ultra-sonic or Soxhlet extraction. The obtained chromatograms can be further analyzed using window factor analysis (WFA), Evolving factor analysis (EFA) and heuristic evolving latent projections (HELP). The study didn't specify which programs were exactly used. However, it concluded that these chemometric techniques can greatly reduce the complexity of the produced chromatograms and enhance its resolution for better-fingerprinting analysis. In addition, this study reported great differences between chemical fingerprints of volatile components between fresh and dried ginger samples. However, details were not presented in this work [41]. 
In 2004, Gong et al. used two-dimensional GC-MS coupled with chemometric analysis for the determination of volatile components in both fresh and dried ginger. Chemometric analyses were used to correct the baseline drifting, detect the purity of the obtained peaks, identify the number of the chemical constituents present and moreover, enhance the resolution of the produced chromatograms and mass spectral data. The results showed that most of the volatile constituents of fresh and dried ginger are similar despite their different pharmacological activities [42].

Later on, He et al. (2010) used the same previous approach (42)for the detection of differences between volatile constituents of the essential oil of fresh ginger (Zingiber officinale Roscoe), dried ginger (Rhizome Zingibers) and scarfskin of fresh ginger (Ginger peel). A total of 85,81 and 80 volatile constituents were determined from the three essential oils, respectively with 52 volatile components were common between the three oils. In conclusion, the study proved this method as effective for the analysis of complex systems as Chinese traditional medicine and can be used successfully for the quality assessment of products in the food industry [43].

In 2013, Rafi et al. used reverse phase capillary liquid chromatography (RP-CLC) for instantaneous determination of four components (6-, 8-, 10-gingerol and 6-shogaol) found in ginger. Thirty-seven samples of three varieties of ginger growing in Indonesia (Z. officinale var. amarum), (Z. Officinale var. office-Narum) and (Z. officinale var. rubrum) were studied. The results showed that the four compounds were not enough to distinguish between the three varieties. By applying discriminant analysis (DA), 100\% correct classification of each analyzed group (three varieties) was achieved. Cross-validation was used for evaluation of the predictive ability of the classifying model and it was found that $94 \%$ of all the samples were correctly classified [44].

Feng et al. (2014) used HPLC-PDA for fingerprint analysis of 10 batches of ginger from different markets in China coupled with the chemometric techniques including similarity analysis, hierarchical clustering analysis and principal component analysis of the ginger samples. The results showed that chemometric analyses classified 10 batches of ginger to two groups reflecting quality differences between these samples [39].

Later on, Yudthavorasit et al. (2014) adopted an HPCL-DAD method combined with chemometrics for classification of ginger (Zingiber officinale) according to geographical origins including five different producing countries. This method involved the use of 6-, 8-, 10-gingerols as the reference standard. The chromatographic peaks were identified using mass spectrometry and eight particular peaks identified by mass spectrometry were used for further discriminative analysis. Chemometric analyses were performed using similarity analysis, HCA, PCA, and linear discriminant analysis (LDA). The method showed to be a practical tool that was suitable for originating and authentication of unclassified ginger samples. In addition, it could be used to detect quality control and food authenticity concerns regarding ginger origin by analyzing unknown ginger samples and processing the produced data with chemometrics. Furthermore, this study showed that different markers could be used for specifying of ginger from different geographical origin, where 8gingerol and methyl- 6-gingerol are selective markers for detecting ginger from India and Thailand, respectively while methyl diacetoxy-8gingerdiol, 10-gingerol, and diacetoxy-8gingerdiol can be specifically used as markers for Chinese ginger [45]. 
Recently, Maiset al. (2018) used UPLCQ/TOF-MS coupled with Metabolomics as an approach for discrimination between two ginger cultivars (China) and (Ghana). This study applied the use of identified metabolites of ginger, isolated using UPLC, together with multivariate analysis for the discrimination between two ginger cultivars. Principle component analysis (PCA), Orthogonal Partial least square regression and Soft independent modeling by class analogy (SIMCA) were used for data analysis. The results showed identification of sixteen metabolites were identified, from which six metabolites were assigned as marker compounds for differentiation between Ghanaian and Chinese ginger. As a conclusion, this method was reported as a reliable and successful method for interspecies differentiation between ginger cultivars. However, more samples are needed for wide coverage of different ginger cultivars for accurate detection of the exact metabolites that can be used in its discrimination (Table 3) [46].

Table 3. Quality control of ginger using chromatographic techniques coupled with chemometrics

\begin{tabular}{|c|c|c|c|}
\hline Extraction & Method of analysis & Purpose of the study & Reference \\
\hline $\begin{array}{l}\text { Steam distillation } \\
\text { Ultrasonic Extraction } \\
\text { Soxhlet Extraction }\end{array}$ & $\begin{array}{c}\text { 2D GC-MS } \\
\text { With WFA, EFA, and } \\
\text { HELP }\end{array}$ & $\begin{array}{l}\text { Fingerprinting analysis of } \\
\text { fresh and dried ginger }\end{array}$ & [41] \\
\hline Steam distillation & $\begin{array}{c}\text { 2D GC-MS } \\
\text { With ELPG and } \\
\text { Eigenstructure tracking } \\
\text { analysis }\end{array}$ & $\begin{array}{l}\text { Determination of volatile } \\
\text { components in both fresh and } \\
\text { dried ginger }\end{array}$ & [42] \\
\hline $\begin{array}{l}\text { Standard extraction } \\
\text { method for volatile oil } \\
\text { described by Chinese } \\
\text { pharmacopeia } 2005\end{array}$ & $\begin{array}{c}\text { 2D GC-MS } \\
\text { With heuristic evolving } \\
\text { latent projections } \\
\text { (HELP), ELPG and } \\
\text { Eigenstructure tracking } \\
\text { analysis }\end{array}$ & $\begin{array}{l}\text { Detection of difference } \\
\text { between volatile constituents } \\
\text { of the essential oil of fresh } \\
\text { ginger dried ginger and } \\
\text { scarfskin of fresh ginger } \\
\text { (Ginger peel) }\end{array}$ & {$[43]$} \\
\hline
\end{tabular}




\begin{tabular}{|c|c|c|c|}
\hline $\begin{array}{l}\text { Methanol extract } \\
\text { Isocratic elution } \\
\text { Mobile phase: } \\
60 \% \text { acetonitrile }\end{array}$ & $\begin{array}{c}\text { RP_CLC-UV with } \\
\text { DA }\end{array}$ & $\begin{array}{l}\text { Instantaneous determination } \\
\text { of four components (6-, 8-, } \\
\text { 10-gingerol and 6-shogaol) } \\
\text { in three varieties of ginger } \\
\text { (Z. officinale var. amarum), } \\
\text { (Z. Officinale var. office- } \\
\text { Narum) and (Z. officinale } \\
\text { var. rubrum) }\end{array}$ & [44] \\
\hline $\begin{array}{l}\text { Methanol extract } \\
\text { Linear gradient elution } \\
\text { Mobile phase: } \\
\text { Acetonitrile } \\
\text { and } 0.1 \% \text { phosphate in } \\
\text { water }\end{array}$ & $\begin{array}{c}\text { HPLC-PDA } \\
\text { with HCA and PCA }\end{array}$ & $\begin{array}{l}\text { To establish an efficacious } \\
\text { and combinational method } \\
\text { and pattern recognition } \\
\text { technique for quality control } \\
\text { of ginger. }\end{array}$ & [39] \\
\hline $\begin{array}{l}\text { Methanol extract } \\
\text { Binary gradient elution } \\
\text { Mobile phase: } \\
\text { Water: Acetonitrile }\end{array}$ & $\begin{array}{c}\text { HPLC-DAD } \\
\text { with SA, HCA, PCA, } \\
\text { and LDA }\end{array}$ & $\begin{array}{l}\text { Classification of } \text { ginger } \\
\text { according to geographical } \\
\text { origin including five } \\
\text { different } \\
\text { countries. }\end{array}$ & [45] \\
\hline $\begin{array}{l}\text { Methanol extract } \\
\text { Gradient elution } \\
\text { Mobile phase: } \\
\text { Water }+0.1 \% \text { formic acid } \\
\text { : Acetonitrile }\end{array}$ & $\begin{array}{c}\text { UPLC-Q/TOF-MS } \\
\text { with PCA, OPLS, and } \\
\text { SIMCA }\end{array}$ & $\begin{array}{l}\text { Discrimination between fresh } \\
\text { ginger of two different } \\
\text { geographical origins China } \\
\text { and Ghana }\end{array}$ & [46] \\
\hline
\end{tabular}




\section{CONFLICT OF INTEREST}

The authors declare that they have no conflict of interest.

\section{REFERENCES}

1. Kubra IR, Rao LJ. An impression on current developments in the technology, chemistry, and biological activities of ginger (Zingiber officinale Roscoe). Critical Reviews in Food Science and Nutrition 2012; 52(8): 651-88. doi: 10.1080/10408398.2010.505689. PubMed PMID: 22591340.

2. Nurtjahja-Tjendraputra E, Ammit AJ, Roufogalis BD, Tran VH, Duke CC. Effective anti-platelet and COX-1 enzyme inhibitors from pungent constituents of ginger. Thrombosis Research. 2003; 111(4): 259-65.

3. Ali B, Blunden G, Tanira M, Nemmar A. Some phytochemical, pharmacological and toxicological properties of ginger (Zingiber officinale Roscoe): A Review of Recent Research. 2008. 409-20.

4. Afzal M, Al-Hadidi D, Menon M, Pesek J, Dhami M. Ginger: an ethnomedical, chemical and pharmacological review. Drug metabolism and drug interactions. 2001;18(3-4): 159-90.

5. Pakrashi SC, Pakrashi A. Ginger: A versatile healing herb: Vedams eBooks (P) Ltd; 2003.

6. Gregory PJ, Sperry M, Wilson AF. Dietary supplements for osteoarthritis. American Family Physician. 2008;77(2).

7. Keating A, Chez RA. Ginger syrup as an antiemetic in early pregnancy. Alternative therapies in health and medicine. 2002; 8(5): 89.

8. Borrelli F, Capasso R, Aviello G, Pittler MH, Izzo AA. Effectiveness and safety of ginger in the treatment of pregnancy-induced nausea and vomiting. Obstetrics \& Gynecology. 2005; 105(4): 849-56.

9. Tao Y, Li W, Liang W, Van Breemen RB. Identification and quantification of Gingerols and related compounds in Ginger dietary supplements using High-Performance Liquid Chromatography-Tandem Mass Spectrometry. Journal of Agricultural and Food Chemistry. 2009; 57(21): 10014-21. doi: $10.1021 /$ jf9020224.
10. Hostettmann K, Marston A, Hostettmann M Preparative chromatography techniques: Springer; 1986.

11. Connell D, McLachlan R. Natural pungent compounds: IV. Examination of the gingerols, shogaols, parasols and related compounds by thin-layer and gas chromatography. Journal of Chromatography A. 1972; 67(1): 29-35.

12. Melianita F, Cholifah S, Summerlin E, Kartinasari WF, Indrayanto G. Simultaneous Densitometric determination of 6-Gingerol and 6-Shogaol in some commercial Gingers (Zingiber Officinale Roscoe). Journal of Liquid Chromatography \& Related Technologies. 2007; 30(19): 2941-51.

13. Mukherjee PK, Houghton PJ. Evaluation of herbal medicinal products: Pharmaceutical Press; 2009.

14. Melianita F, Witha J, Arifin S, Kartinasari WF, Indrayanto G. Simultaneous densitometric determination of 6-gingerol, 8-gingerol, 10gingerol, and 6-shogaol in some commercial gingers. Journal of Liquid Chromatography \& Related Technologies. 2009; 32(4): 567-77.

15. Yusufoglu H, Alqasoumi SI. High-Performance Thin layer chromatographic analysis of 10Gingerol in Zingiber officinale extract and Ginger-containing dietary supplements, teas and commercial Creams. FABAD Journal of Pharmaceutical Sciences 2008; 33:199-204.

16. AL-Qasoumi SI. Quantification of 6-gingerol in Zingiber officinale extract, ginger-containing dietary supplements, teas and commercial creams by validated HPTLC densitometry. FABAD Journal of Pharmaceutical Sciences 2009; 34: $33-42$.

17. Khan I, Pandotra P, Gupta AP, Sharma R, Gupta BD, Dhar JK, et al. RP-thin layer chromatographic method for the quantification of three gingerol homologs of ultrasonic-assisted fresh rhizome extracts of Zingiber officinale collected from North Western Himalayas. Journal of Separation Science. 2010; 33(45):558-63. doi: 10.1002/jssc.200900629.

18. Salmon CNA, Bailey-Shaw YA, Hibbert S, Green C, Smith AM, Williams LAD. Characterization of cultivars of Jamaican ginger (Zingiber officinale Roscoe) by HPTLC and HPLC. Food Chemistry. 2012; 131(4):1517-22. doi: 10.1016/j.foodchem.2011.09.115.

19. Baranowski J. High-performance liquid chromatographic separation of pungency 
components of ginger. Journal of Chromatography A. 1985; 319: 471-4.

20. Chen CC, Kuo MC, HO CT. High performance liquid chromatographic determination of pungent gingerol compounds of ginger (Zingiber officinale Roscoe). Journal of Food Science. 1986; 51(5): 1364-5.

21. He X-g, Bernart MW, Lian L-z, Lin L-z. Highperformance liquid chromatography-electrospray mass spectrometric analysis of pungent constituents of ginger. Journal of Chromatography A. 1998; 796(2): 327-34.

22. Balladin D, Headley O, Chang-Yen I, McGaw D. High pressure liquid chromatographic analysis of the main pungent principles of solar dried West Indian ginger (Zingiber officinale Roscoe). Renewable Energy. 1998; 13(4): 531-6.

23. Saha S, Smith RM, Lenz E, Wilson ID. Analysis of a ginger extract by high-performance liquid chromatography coupled to nuclear magnetic resonance spectroscopy using superheated deuterium oxide as the mobile phase. Journal of Chromatography A. 2003; 991(1): 143-50.

24. Schwertner HA, Rios DC. High-performance liquid chromatographic analysis of 6-gingerol, 8gingerol, 10-gingerol, and 6-shogaol in gingercontaining dietary supplements, spices, teas, and beverages. Journal of Chromatography B. 2007; 856(1): 41-7.

25. Li X, Zhu Z-y, Wu Y-t, Chai Y-f, Zhang G-q, Lou Z-y. Rapid and Accurate Analytical Method for the Determination of Gingerols in Three Medicinal Gingers (Zingiber officinale Roscoe) by High-Performance Liquid Chromatography. Analytical Letters. 2008; 41(10): 1732-41. doi: $10.1080 / 00032710802162277$.

26. Shao X, Lv L, Parks T, Wu H, Ho C-T, Sang S. Quantitative analysis of ginger components in commercial products using liquid chromatography with electrochemical array detection. Journal of Agricultural and Food Chemistry. 2010; 58(24): 12608-14.

27. Park JS, Jung MY. Development of highperformance liquid chromatography-time-offlight mass spectrometry for the simultaneous characterization and quantitative analysis of gingerol-related compounds in ginger products. Journal of Agricultural and Food Chemistry. 2012; 60(40): 10015-26.
28. Chen CC, Ho CT. Gas chromatographic analysis of volatile components of ginger oil (Zingiber officinale Roscoe) extracted with liquid carbon dioxide. Journal of Agricultural and Food Chemistry. 1988; 36(2): 322-8. doi: 10.1021/jf00080a020.

29. Nishimura O. Identification of the characteristic odorants in fresh rhizomes of ginger (Zingiber officinale Roscoe) using aroma extract dilution analysis and modified multidimensional gas chromatography-mass spectroscopy. Journal of Agricultural and Food Chemistry. 1995; 43(11): 2941-5.

30. Shao Y, Marriott P, Shellie R, Hügel $H$. Solid-phase micro-extraction-comprehensive two-dimensional gas chromatography of ginger (Zingiber officinale) volatiles. Flavour and Fragrance Journal. 2003; 18(1): 5-12.

31. Yu Y, Huang $\mathrm{T}$, Yang B, Liu X, Duan G. Development of gas chromatography-mass spectrometry with microwave distillation and simultaneous solid-phase microextraction for rapid determination of volatile constituents in ginger. Journal of Pharmaceutical and Biomedical Analysis. 2007; 43(1): 24-31. doi: http://dx.doi.org/10.1016/j.jpba.2006.06.037.

32. Yang Z-n, Yang W, Peng Q, He Q, Feng Y, Luo S, et al. Volatile phytochemical composition of the rhizome of ginger after extraction by headspace solid-phase microextraction, petrol ether extraction, and steam distillation extraction. Bangladesh Journal of Pharmacology. 2009; 4(2): 136-43.

33. Sasidharan I, Menon AN. Comparative chemical composition and antimicrobial activity fresh \& dry ginger oils (Zingiber officinale Roscoe). Int J Curr Pharm Res. 2010; 2(4): 40-3.

34. Shinde Sachin K, Grampurohit N, Banerjee S, Jadhav S, Gaikwad D. Development and validation of UV spectroscopic method for the quick estimation of gingerol from Zingiber officinale rhizome extract. International Research Journal of Pharmacy 2012; 3(5): 234-7.

35. Zhang Y-B, Shaw P-C, Sze C-W, Wang Z-T, Tong Y. Molecular authentication of Chinese herbal materials. Journal of Food and Drug Analysis. 2007; 15(1).

36. Chavan P, Warude D, Joshi K, Patwardhan B. Development of SCAR (sequence-characterized amplified region) markers as a complementary 
tool for identification of ginger (Zingiber officinale Roscoe) from crude drugs and multicomponent formulations. Biotechnology and Applied Biochemistry. 2008; 50(1): 61-9. doi: 10.1042/BA20070128.

37. Jiang H, Xie Z, Koo HJ, McLaughlin SP, Timmermann BN, Gang DR. Metabolic profiling and phylogenetic analysis of medicinal Zingiber species: Tools for authentication of ginger (Zingiber officinale Rosc.). Phytochemistry. 2006; 67(15): 1673-85.

38. Chaudhary AA, Khan M, Al-Shaqha WM, Alharbi M, Al-Khamees OA. Rapid and easy molecular authentication of the medicinal plant Zingiber officinale Roscoe by loop-mediated isothermal amplification (LAMP)-based marker. Journal of Medicinal Plants Research. 2014; 8(20): 756-62.

39. Feng X, Kong W, Wei J, Ou-Yang Z, Yang M. HPLC fingerprint analysis combined with chemometrics for pattern recognition of ginger. Pharmaceutical Biology. 2014; 52(3): 362-7.

40. Gad HA, El-Ahmady SH, Abou-Shoer MI, Al-Azizi MM. Application of chemometrics in the authentication of herbal medicines: a review. Phytochemical Analysis. 2013; 24(1): 1-24.

41. CHAU F-t, MOK DK-w, GONG F, TSUI S-k, WONG S-k, HUANG L-Q, et al. Fingerprinting analysis of raw herb: application of chemometrics techniques for finding out chemical fingerprint of Chinese herb. Analytical Sciences/Supplements. 2001;17(0): a419-a22.

42. Gong F, Fung Y-S, Liang Y-Z. Determination of Volatile Components in Ginger Using Gas Chromatography-Mass Spectrometry with Resolution Improved by Data Processing Techniques. Journal of Agricultural and Food Chemistry. 2004; 52(21): 6378-83. doi: 10.1021/jf040102z.

43. He Y, Li X-R. Analysis of Volatile Components In Rhizome Zingibers, Zingiber Officinale Roscoe And Ginger Peel By Gas Chromatography-Mass Spectrometry and Chemometric Resolution. 2010.

44. Rafi M, Lim LW, Takeuchi T, Darusman LK. Simultaneous determination of gingerols and shogaol using capillary liquid chromatography and its application in discrimination of three ginger varieties from Indonesia. Talanta. 2013; 103: 28-32.
45. Yudthavorasit S, Wongravee K, Leepipatpiboon N. Characteristic fingerprint based on gingerol derivative analysis for discrimination of ginger (Zingiber officinale) according to geographical origin using HPLC-DAD combined with chemometrics. Food chemistry. 2014; 158:10111.

46. Mais E, Alolga RN, Wang S-L, Linus LO, Yin X, Qi L-W. A Comparative UPLC-Q/TOF-MSbased Metabolomics approach for distinguishing Zingiber officinale Roscoe of two geographical origins. Food Chemistry. 2018; 240: 239-44. 